The 'Journal of African Languages'

The first number of the Journal of African Languages (see Africa, July 196r, p. 286) has recently been published and contains the following articles:

A Re-classification of South African Non-Bantu Languages

Bantu Origins: A Tentative New Hypothesis

The Interpretation of the Coptic Vowel System

Influence of Analogy in African Languages

Des Noms Songhay dans l'Ahaggar

Rárà : A Yoruba Chant

Nom et Verbe dans les Langues Mandé

The Phonology of Kpelle
E. Westphal

M. Guthrie

J. H. Greenberg

A. Klingenheben

J. Clauzel

H. Wolff

G. Manessy

W. E. Welmers.

The journal will be published three times a year. The annual subscription of $36 s$. sterling or \$s should be sent to Macmillan \& Co. Ltd., St. Martin's Street, London, W.C. 2. Manuscripts for publication should be addressed to the Editor, Professor J. Berry, School of Oriental and African Studies, University of London, London, W.C. I.

\title{
The West African Languages Survey ${ }^{\mathbf{I}}$
}

THE second West African Languages Congress, 'La Semaine Linguistique', was held at the University of Dakar from 13 to 17 April 1962 . It was opened by His Excellency M. Léopold Senghor, President of Senegal, with M. Franck, Rector of the University, and the Diplomatic Corps in attendance. M. Senghor addressed the meeting and then expressed his personal and official interest in West African linguistics by presiding during the reading of the first paper and the lively discussion which followed it. In the evening he met the participants at a reception in the Presidential Palace.

The Congress was attended by over fifty persons from all parts of West Africa and from Great Britain, the U.S.A., France, Germany, Austria, and Holland. Its central theme was 'The Verb in West African Languages', but many papers on other topics were also given. Local arrangements and hospitality were organized by IFAN and the University of Dakar, with assistance from the Government of Senegal, the West African Languages Survey, and Unesco.

The West African Languages Survey has awarded two fellowships for field research for 1962-3. Dr. Bôt ba Njock is to study the languages near his home in the Bassa district of the Republic of the Cameroun. He is the first African Fellow of the Survey. Dr. David $\mathrm{Crabb}$ of Columbia University is to study Ekoi and related languages in Eastern Nigeria. One fellowship remains to be assigned at the time of the third West African Languages Congress, to be held at the University College of Sierra Leone, Freetown, from 27 March to I April 1963. Further information may be obtained from Professor J. H. Greenberg at Columbia University, New York.

During the second year of the Survey's work Dr. Peter Ladefoged of Edinburgh University carried out an extensive instrumental-phonetic study of the sounds of West African languages, using the laboratory facilities at Ibadan, Legon, and IFAN, Dakar. Dr. Carl Hoffmann of Hamburg studied Kambari and related languages in Kontagora Emirate, Nigeria. Miss Mary Lynn Morse of Columbia University studied Black Bobo and other languages of the Republic of Upper Volta. Miss Margaret Hoffmann of Hartford Seminary, Connecticut, remained in the field during most of the year to continue her study of the socalled 'Remnant Languages' of Ghana and Togo.

\section{(Communicated by Professor Robert G. Armstrong) \\ I See also Africa, July ig62, p. 288.}

